\title{
In Memorial
}

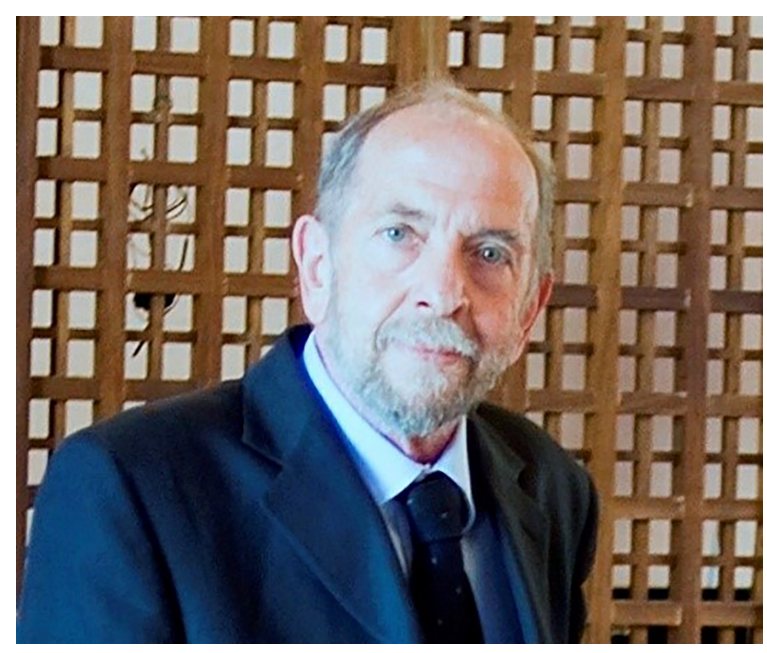

Our family is really happy and honored for this initiative of Professor Bonavida, and for this we thank him warmly. Our memory of Dad is linked not so much to his professional activity, which always made us proud, but mainly to the time he dedicated to us. He was a person with a character that, at first, could seem gruff and reserved but to those who had the good fortune to know him and to be close to him he revealed himself for what he really was; that is, a person with elegant ways, a superfine intelligence and certainly a personal but no less appreciated way of showing his affection. The memories together, of course, are many; among the most beautiful are the many carefree trips, characterized by a strong spirit of freedom. We often traveled in caravans, we went camping, during the Christmas holidays we all went to the mountains to ski together. We children also fondly remember the many trips he made with our mother around the world, often to follow some medical event to which he was invited. Dad had many passions: tennis, long walks in the mountains, ping pong, sailing. He loved music and theater; in fact, every weekend with our mother they went to listen to classical music concerts. Small anecdotes that we always remember with affection, which describe his soul, concern a rainy evening when he brought home a few-days-old kitten found near his car, or when he tried to transform a rubber dinghy into a small sailboat using a broomstick and an old sheet. But, his greatest passion was certainly his work, and we always remember him studying something or preparing lessons for his students, some of whom have remained emotionally attached to him. We miss Dad so much; today more than ever, people like him, characterized by a strong ethics and moral charge, who are serious, balanced, and cultured, are really rare. In these particularly difficult and insidious times it would have been nice to have him with us as a lighthouse or a star to follow so as not to lose the course. Wherever you are Daddy or Nanni, as many called you, we love you. We miss you, please watch over us.

Your family,

Giulia D'Alessandro (Wife)

Giuseppe D'Alessandro (Son)

Antonio (Son)

Teresa (Daughter)

Andrea (Grandchild)

Gabriele (Grandchild) 
